\title{
UNIVERSITYOF
}

FORWARD

THINKING

WESTMINSTER用

WestminsterResearch

http://www.westminster.ac.uk/westminsterresearch

Collective Culpability in Costa Rica: The Case of Quince

Duncan's Kimbo

Harvey-Kattou, L.

This is an Accepted Manuscript of a chapter that has been published in Crime Fiction in Latin America.

The original work can be found at:

https://www.peterlang.com/

(C) Peter Lang AG, 2019.

All rights reserved.

The WestminsterResearch online digital archive at the University of Westminster aims to make the research output of the University available to a wider audience. Copyright and Moral Rights remain with the authors and/or copyright owners.

Whilst further distribution of specific materials from within this archive is forbidden, you may freely distribute the URL of WestminsterResearch: ((http://westminsterresearch.wmin.ac.uk/).

In case of abuse or copyright appearing without permission e-mail repository@westminster.ac.uk 


\title{
Collective Culpability in Costa Rica: The Case of Quince Duncan's Kimbo
}

\begin{abstract}
Despite Costa Rica's peaceful rhetoric, Quince Duncan's 1989 novel, Kimbo, portrays civil society as so corrupt it would rather condemn and kill an innocent man than admit to individual faults. This article therefore considers the nation as a crime scene in Kimbo, whereby the State and its deputies are the perpetrators of several crimes. Using Antonio Gramsci's and Louis Althusser's concepts of the State, civil society and subaltern to discuss the idea of a nationwide, collective culpability, it analyses the roles played by the 'voices' versus the 'voiceless' in the novel. It argues that the former group incorporates Repressive State Apparatus and Ideological State Apparatus, such as the police, judiciary and the Catholic Church, while the latter comprises marginalized groups such as Afro-Costa Ricans, women and the poor.
\end{abstract}

\section{Author Bio}

Dr Liz Harvey-Kattou is a Lecturer in Spanish Language and Culture at the University of Westminster. Her research focuses on national and cultural identity in Latin America, with a focus on ethnicity, gender and sexuality in Costa Rican literature and film. Recent publications include 'The Supernatural as Decolonial Tactic: Afro-Costa Rican Motifs in Quince Duncan's Fiction' in From the Supernatural to the Uncanny (Cambridge Scholars Publishing, 2017) and 'Rendering the Invisible Visible: Reflections on the Costa Rican Film Industry in the Twenty-First Century', in A Companion to Latin American Cinema (Wiley Blackwell, 2017).

Keywords Costa Rica; Central American crime fiction; Quince Duncan; Kimbo; Antonio Gramsci; Louis Althusser. 
Having abolished its armed forces in 1948, Costa Rica - often dubbed the 'Switzerland of Central America' for its love of peace (Christian 2013: 1600) - has long been proud of its political stability, relative economic prosperity and peaceful existence, especially in comparison to its Central American neighbours. Perhaps it is no surprise, then, that relatively few works which could be termed crime fiction have been published in the country. ${ }^{1}$ Indeed, novels such as Carlos Cortés's Cruz de olvido [Cross of Oblivion] (1999), a semi-fictional account of a series of killings which took place in the 1980s, or Daniel Quirós's hardboiled detective mini-series - Verano rojo [Red Summer] (2010) and Lluvia del norte [Rain from the North] (2014) - represent some of the only well-known forays into the genre, despite the robust twentieth and twenty-first century canon of Costa Rican letters. ${ }^{2}$ Considering the broader concept of the 'crime scene' as a key tenet of crime fiction, however, it is clear to see that the nation as complicit in - and perhaps also as the perpetrator of - crimes against its citizens is a more common literary trope in the country, especially in the social protest years of the 1970s and 1980s. ${ }^{3}$ As a major author of this generation, Quince Duncan's novels revolve around critique of injustices perpetrated within Costa Rican society, often with a specific focus on prejudice against Afro-Costa Ricans. However, in his 1989 novel, Kimbo, Duncan expands his focus. Crime is at the heart of this complex, wide-ranging narrative in which the victims are marginalized members of society, the scene of the crime is the nation itself and the culpable parties are civil society and the State, which both operate through hegemonic capitalist ideology.

Using a mixture of first, second and third person narration, Kimbo principally tells the story of the life of its eponymous protagonist, a young Afro-Costa Rican man, before and after he is falsely accused of kidnapping a white, wealthy local businessman, known as El Barrigón [The Potbelly]. Despite not being anywhere near the crime scene when the kidnapping was committed, it appears that Kimbo fits the public's perception of a criminal too well to be discounted - he is black, from a poor, rural slum, and is now attempting to start a business

\footnotetext{
${ }^{1}$ According to Andrea Pezze, the Central American nations that experienced civil wars and dictatorships in the twentieth century and which are now dealing with increased levels of violence, drug trafficking and gang crime, are currently also seeing a rise in the production of crime fiction as a way of scrutinizing what he terms 'las dinámicas oscuras del poder y de la represión' [the dark dynamics of power and repression] (2016: 10). Daniel Quirós, meanwhile, notes that due to rising crime levels in Costa Rica, crime fiction has become a more popular genre for local authors in the twenty-first century, specifically from 2010 onwards (126-7).

${ }^{2}$ For more on Costa Rican literature see Quesada Soto, 2008; for more on contemporary crime fictions in Costa Rica see Quirós, 2017.

${ }^{3}$ Quesada Soto notes that works from this era began to question and actively challenge the repressive identity norms of the nation (2008: 103).
} 
and live among the middle classes in the capital city. Indeed, although no one saw him at the scene, the novel begins in court as 'witnesses' testify against Kimbo, all sure that he committed the crime. Although the truth of the kidnapping - committed by the fictional vigilante group known as the Comité Nacional de Defensa Cívica (CNDC) [National Civic Committee for Defence] - is eventually made clear to the reader, justice is not done as even when El Barrigón is released and Kimbo is freed, he is still seen as guilty in the eyes of the media and is forced to live in exile. In the novel's denouement, upon returning to Costa Rica to clear his name after a short period spent in Panama, ${ }^{4}$ Kimbo is shot and killed at the airport by an unknown perpetrator. A few weeks after his death, seventy copies of a letter exposing the false witnesses who testified against Kimbo arrive on the doorstep of all parties involved, and corruption is thereby exposed at every level of society. The story is told through a cast of characters who are identified by their role rather than by name - the policeman, the court clerk, the lawyer, the ex-wife, the new wife, the businessman and the businessman's wife. It is their accounts which allow Duncan to deal with issues of corruption, individualism, racism and sexism, and it is this critique that has led González Zúñiga to note that Kimbo is 'una novela de aires existencialistas y muchas interrogantes sobre la realidad de nuestra sociedad' [a novel with an air of existentialism which questions the reality of our society] ${ }^{5}$ (2014: 398). This idea of the novel as questioning accepted social norms and values forms the basis of this chapter as it will consider how Kimbo can be read in light of Louis Althusser and Antonio Gramsci's Marxist critiques of social order, demonstrating the extent to which the triumph of individualism over community results in criminal injustice. When considering how norms and hegemonic attitudes are maintained and perpetuated in societies, ${ }^{6}$ Althusser states that this cycle requires 'a reproduction of its submission to the rules of established order' (1971: 132), as well as contending that this established order is 'integrated into our everyday consciousness' (1971: 128). This chapter will therefore begin by analyzing the established social order of hegemony, civil society and the subaltern in Kimbo, demonstrating the ways in which Duncan has conceived of the perpetrators and victims of the crimes of Costa Rican society, before examining the culprit - the cult of individualism.

\section{The Perpetrators: Civil Society}

\footnotetext{
${ }^{4}$ While the novel does not specify how long Kimbo has been in exile, it is clear that the case is still fresh in both the public imagination and in the conversations held by the actual perpetrators (137).

${ }^{5}$ All translations are my own.

6 This, Althusser terms the reproduction of the conditions of production (1971: 146-7).
} 
Multiple crimes and injustices are committed in Kimbo - including the kidnapping of $E l$ Barrigón, the false arrest and imprisonment of Kimbo, the failure to arrest the actual kidnappers and Kimbo's murder - and taking Costa Rican society itself as the scene of the crime it becomes clear that these incidents are all interconnected. Indeed, the dangerous social divisions set out within Kimbo mirror those defined by Gramsci and Althusser, and these constitute both the motive and the means by which each violation is committed. According to Gramsci, the State is the governing individual or collective which holds administrative and legal power over the nation, also termed hegemonic rule (in Hoare and Nowell Smith, 1971: 12). Hegemony maintains control through the propagation of its ideals and through the use of civil society, which Gramsci terms to be public-facing institutions influenced by the State, also known as the State's deputies (in Hoare and Nowell Smith 1971: 12). Althusser furthers this definition by dividing civil society into two groups: the Repressive State Apparatus (RSA) and the Ideological State Apparatus (ISA) (1971: 142-3). He contends that the RSA are necessarily institutions in the public domain which, in order to control individuals, use violence first and ideological persuasion later. He argues that the ISA, on the other hand, are made up of institutions which act in the private domain, and which use ideology first and repression as a secondary tool with which to control society (1971: 142-3). The San José of Duncan's novel fits firmly within these definitions of a controlling and often repressive society whereby the hegemonic State wields power over its citizenry. The RSA and ISA are embodied by certain characters in Kimbo, with the former referring to the policeman, the court clerk and administrative bureaucracy, and the latter comprising the Catholic Church, all of whom are the perpetrators of injustice in the novel.

The police in Kimbo are seen as no more than violent and corrupt government puppets, intimidating and beating their suspects to force a confession. Indeed, the President of the Republic calls the police to demand a confession from Kimbo, and the policeman's words demonstrate his complicity in this injustice as he states: 'la verdad es que esa noche lo hubiéramos hecho cantar, o inventar una historia que es todo lo que estaba pidiendo el ministro' [the truth is that that night we would have made him talk, or invent a story which was all the ministry was asking for] (100). ${ }^{7}$ The policeman operates according to Althusser's definition of the RSA as in order to extract this confession he resorts to violence first and persuasion later. He narrates: 'Hijo de mala madre le dije de nuevo gritando y le metí el

\footnotetext{
${ }^{7}$ All citations from: Quince Duncan, Kimbo (Costa Rica: Editorial Costa Rica, 1989).
} 
chuzo. Y casi mato al carajo' [Son of a bitch I screamed at him again and I skewered him. And I almost kill the fucker] (26), demonstrating his use of violence to assert control. Duncan then uses irony to expose the absurdity of maintaining established order, as although the hegemonic power wants a confession forced from Kimbo, the policeman states that he would be in trouble if Kimbo died as torture does not 'officially' exist in Costa Rica (28). Upon failing to elicit a confession through violence, then, the policeman goes on to use coercion as his secondary tool to perform the State's request as he threatens to gang rape Kimbo's wife unless he confesses. This threat hangs over the protagonist after the more graphic depiction of violence has ended, and the policeman's attempt to absolve himself of responsibility for these actions is also written to be provocative: 'son cosas del oficio. Es un trabajo feo, lo acepto, pero no me da pena decir que alguien tiene que hacer la parte fea' [it's part of the profession. It's an ugly job, I accept that, but I'm not ashamed to say that someone has to do the dirty work] (29). It is through this use of conflicting and ironic moral pronouncements, then, that the reader is invited to reflect on social values rather than the graphic images associated with some hardboiled crime fiction. With this lack of graphic violence, Duncan appears to adhere to the twentieth century trend within Costa Rican crime narratives, as noted by Daniel Quirós, of focusing on social and political critique and the corruption of government and society rather than narrating violence against the individual (2017: 126). ${ }^{8}$ As such, Kimbo challenges the reader to consider the implications of maintaining an unquestioning attitude toward achieving a desired outcome in the name of a national or common good, demonstrating that it is actually worse for society as a whole when norms go unchallenged. The judiciary is used in a similar way to the police in the novel as, although revered as a source of national pride since the 1948 revolution (Biesanz et al 1999: 65), it is described in Kimbo as nothing more than a facade, ruled by the press and the government's whims. Indeed, before the trial has even begun, the reader is told that Kimbo will be found guilty: 'Culpable. Esa iba a ser la verdad: la única certidumbre' [Guilty. This was going to be the truth: the only certainty] (15), because Kimbo has been tried and found guilty by the media prior to his case arriving in court. Moreover, the judge is described as:

\footnotetext{
${ }^{8}$ Quirós notes that twenty-first Costa Rican crime fiction tends to be influenced more by the hardboiled genre, especially those featuring lone investigators, and he puts this down to an increase in violent crime and the uncovering of corruption in the country $(2017: 126)$.
} 
Cansado [...] Cansado de los que se dedican a sí mismos y están ricos [...] Cansado de los editoriales que habían enjuiciado al reo y dictado sentencia. Cansado de intuir que de alguna manera la justicia sobra.

[Tired [...] Tired of those that only care about themselves and are rich [...] Tired of the newspapers that had judged and sentenced the accused. Tired of suspecting that, in a way, justice is surplus to requirements.] (21)

This repetition of the judge's tiredness evokes the image of an unchanging, static system, maintained and perpetuated by those in power in order to maintain their power, a system in which the judge has little say when justice can be bought by the ruling classes through bribery and media sensationalism. ${ }^{9}$ While the police follow the RSA tactic of using violence to control, the judiciary is seen to use a type of epistemic violence - sentences being decided before a court case has even begun and concealing evidence - to exert the State's hegemony in order to maintain social order. Just as with the policeman, the justification of this corruption as necessary for the common good is repeated by the court clerk as he states that his is also 'un trabajo feo' [an ugly job] (35) that someone has to do. This pronouncement occurs after the clerk uncovers the true perpetrators of the kidnapping, but chooses to say nothing, arguing that he is merely following orders from above (35). The State's ideals which it uses to maintain its power are therefore seen to be inculcated in civil society, and while following orders renders these public servants complicit in crime and corruption, it also demonstrates the extent to which the hegemonic power asserts control over them as its deputies as well as over the rest of society too.

One way in which the State asserts this control over civil society is through the medium of repetitive bureaucracy and administration, which play key roles in the crimes committed in Kimbo. The court clerk states that he must clock in and out from work at a specific time - one minute late upon entry and he must exit one minute late - and yet all he does during the day is have coffee with colleagues and stamp and sign forms left on his desk (32). The repetition of the words 'tacha y firma' [stamp and sign] throughout the clerk's first-person narratives demonstrate the ways in which habits, when perpetuated, become norms not to be broken.

\footnotetext{
${ }^{9}$ While the status of press freedom in Costa Rica has long been highly ranked on account of its journalistic freedoms, tabloid sensationalism, front page 'scandals', and trial by media are often common themes in print media in the country.
} 
The idea of social habitus is formulated by Bourdieu as a system of social norms which are performed and maintained by all, with each individual thereby becoming 'wittingly or unwittingly... a producer and reproducer of objective meaning' (Bourdieu 1977: 79). The fact that the court clerk repeats his daily routine in each section - his morning shower, his daily coffee and so on - demonstrates the extent to which individuals have a collective responsibility to question and break with these habits when they harm others; something the clerk does not do when he does not denounce Kimbo's false conviction in favour of going about his daily routine. That all the public bodies seen in the novel are more concerned with following orders than with the ideological fulfilment of their role in society - which should be to deliver justice - demonstrates the extent to which the unthinking repetition of acts, or the reproduction of the terms of production, can be a harmful activity.

While the individuals representing the RSA in Costa Rica use some sort of violence or repression before ideological persuasion in order to maintain the State's control, then, it is principally the Catholic Church which is presented as an ISA in Kimbo. Rather than see the Church as a space of refuge in this novel, Duncan subverts this traditional image and turns it into a den of corruption, demonstrating how much the Priest has internalized negative societal norms and thus perpetuates harmful social divisions. The Priest is one of the witnesses who testifies against Kimbo, and the omnipresent narrator states that 'Kimbo se lo creyó, porque como siervo de Dios el sacerdote no podía mentir' [Kimbo believed him, because as a servant of God the Priest could not lie] (15), thus showing the ideological power of the Church in society. In this way, Kimbo is seen to be so indoctrinated by these controlling powers that he trusts this representative of the Church more than his own recollections. Moreover, just as with the court clerk and the policeman, the Priest seeks to convince himself that he was merely fulfilling his moral duty when testifying: he claims he saw a black man near the site of the kidnapping and because others said it was Kimbo he went along with it. Again, Duncan denounces the practice of unquestioningly following established social order, and the injustice of the Priest's actions is felt even more acutely when he states his rationale: 'Es verdad que todos los negros se parecen, pero estaba seguro de haberlo visto porque había otras personas que también lo habían visto' [It's true that all black people look alike, but I was sure I had seen him because other people had also seen him] (73). Racism alongside an unquestioning adherence to 'the norm' conspire to encourage the initial false testimony and then to stop the Priest from telling the truth even when he finally admits to himself, via an internal monologue, that he has lied. Rather than concurring 
with the image of the Church as a realm of truth and safety, then, the Church here acts as an ISA which uses its power to maintain the status quo, thereby also unjustly condemning an innocent man in the process.

It is therefore clear that in expressing the ways in which civil society organizations and the individuals employed by them work together for the reproduction of relations of production, Duncan wishes to invite the reader to question their own daily habits and moral judgments which may result in the repression of an individual or group. Indeed, while the fictional outcome of the decisions made by these deputies of the State is death and destruction, as well as the covering up of crimes and corruption, it is their habitual behaviour and mindsets that he chooses to expose through the use of shock value, irony and repetition. This fictional exposure of such behaviour functions as a type of literary resistance, and it is this use of the novel as a form of soft power that is seen in these representations of civil society in Kimbo as the reader begins to uncover and question harmful social norms for themselves.

\section{The Victims: The Subaltern}

While Gramsci and Althusser's theories of social division include the hegemonic power that is maintained by the RSA and ISA, Gramsci labels voiceless individuals or groups existing at the margins of society as subalterns (in Hoare and Smith 1971: 12). Unlike the deputies of the State who are shown to have a voice and power over the narrative in Kimbo, several other characters in the novel are seen to be the voiceless victims of civil society. Indeed, despite his role as protagonist of the novel, Kimbo - who is the only named character - is not given first-person narrative agency, instead he is both spoken to and spoken about by second- and third-person narrators - labelled 'voices' - thus demonstrating his marginal position in the wider landscape of Costa Rica. His voicelessness is alluded to overtly as he is described within the text as 'Kimbo el silencioso' [Kimbo the silent one] (13) who does not speak when being questioned by police, nor at his own trial, nor to his cellmate while in prison. In fact, throughout the novel no direct reported speech is written for Kimbo, which suggests an even greater lack of control over his actuality, and the only time the reader is given access to his voice is through the recollections of others. The reasons for his lack of agency and voice are seen to be intersectional in Kimbo, as not only is he an Afro-Costa Rican and therefore part of a marginalized minority group, but he also grew up in abject poverty and had to fight to get out of the slums. The first voice, one of Kimbo's childhood friends, explains this when he 
states: 'es que ese muchacho está ya en la cumbre y es negro y eso les molesta' [it's that this guy has reached the top and he's black and that annoys them] (49), the 'them' he refers to being civil society. In the novel, however, the reader is made to side with Kimbo over these corrupt State deputies, creating a traditional 'hero' versus 'villain' crime fiction dichotomy. Indeed, while Duncan mainly uses irony over emotive language in his treatment of the RSA and ISA, he employs the latter to force the reader to empathize with Kimbo. When in court, Kimbo is described as 'con los kilómetros de historia cargando sobre él como leyenda' [with the kilometres of history weighing on him like a legend] (13), reminding the reader that Kimbo is descended from slaves and labourers who have been discriminated against for centuries and who, quite literally, have had heavy burdens to bear each day.

Duncan also makes it clear that this prejudice is not just left behind in the history books, as both the Priest and policeman demonstrate the part racism plays in Kimbo's arrest. The Priest exclaims that 'me he fijado bien y todos se parecen. Realmente Dios hizo todos los negros muy, muy parecidos' [I got a good look and they all look the same. God really made all black people very, very similar] (111), thereby perpetuating the commonly repeated racist trope that all black people look alike, while the policeman states of Kimbo's lack of confession: 'Eso sí no lo perdono, y mucho menos en un condenado negro. Porque es bien negro el mulo este' [This I cannot forgive, and much less from a damned black guy. Because this mule here is really black] (26). The injustice of Kimbo's arrest as based on racism is therefore keenly felt by the reader, and this effect is heightened as other harmful stereotypes which demonstrate the marginalized position of Afro-Costa Ricans also abound in the novel. Indeed, this community is viewed by wider society as either dangerous, violent and criminal, or as an entertaining spectacle. While the policeman and Priest emphasize this former idea, Kimbo's cellmate in prison highlights the latter. Indeed, surprised by Kimbo's silence, the cellmate proclaims that black people are meant to be loud, vibrant characters (46), going on to explain that when his father travelled to Limón and stared at the first black person he saw, this man laughed at his curiosity. He continues to state that:

y así es tu gente [...] ¿Por qué vos no soltás la carcajada? Tu gente sabe reírse en los peores momentos. No hay derecho a que pongas esa cara: vos sos de Limón, sos negro, tenés que haber aprendido a reírte. 
[and that's what your people are like [...] Why don't you laugh out loud? Your people know how to laugh in the worst moments. You don't have the right to make this face: you're from Limón, ${ }^{10}$ you're black, you have to have learnt to laugh.] (47)

Clearly, being imprisoned for a crime he has not committed after having been tortured by police is no laughing matter, but Duncan plays with this prevalent stereotype of the AfroCosta Rican as a source of wonderment and entertainment in order to expose its manipulative properties which encourage him not to complain of racist treatment due to this 'positive' perception.

It is not just racism which is reproduced by civil society and used against the subaltern in this novel, however, as class prejudice is also a factor in the injustices perpetrated in Kimbo. The importance of class as structuring subalternity is noted by John Beverley as he states that, above all else, subalternity is wrapped up in class: 'class is the form of subalternity that structures the others' (1999: 166). Indeed, Kimbo himself forms part of this Gramscian conception of the subaltern as he grew up in a slum on the periphery of mainstream society, leaving him disenfranchised and without any social standing. Despite Duncan portraying Kimbo as having successfully worked his way into the middle classes, moving from Limón to San José in the process, he also states of his imprisonment: 'no era la primera situación opresiva que enfrentaba Kimbo. Hubo una vez que la opresión tuvo ropaje de pobreza, pero él pudo levantarse y decir, heme aquî [this was not the first oppressive situation Kimbo had faced. There was a time when oppression wore the cloak of poverty, but he had been able to rise up and say here $I \mathrm{am}](16)$. With this statement Duncan demonstrates that those living in poverty in Costa Rica are not seen as part of society, unable to even exist - state 'heme aquí' [here I am] - until they have risen up. Although Kimbo managed this task, he is still marked out for discrimination and set up for a crime he did not commit while living among the middle classes.

In Duncan's positioning of Kimbo as a subaltern, he also demonstrates the potential power of this group to disrupt established order due to their cultural difference, contending that this is the reason for their vilification and mistreatment by civil society. In direct contrast to San José's individualist society, Limón and the Afro-Costa Rican community are seen as united

\footnotetext{
${ }^{10}$ Limón is one of Costa Rica's seven provinces; it lies on the Caribbean coast and is the only majority AfroCosta Rican province in the country.
} 
by community spirit. The first voice claims that 'necesitamos tener raíces' [we need to have roots] and that 'nosotros, los viejos, mientras quede uno solo de nosotros vivos, vamos a ser eso para él: sus raíces' [us, the older generation, even when only one of us is left, we will be that for him: his roots] (49) showing the extent to which a whole community supports Kimbo. This strong, affective bond between generations is also what gives Kimbo the power of the Semamfo $^{11}$ - an ancestral power derived from African spiritualism - which he uses to send the accusatory letter after his death. It is the distribution of this letter which also demonstrates the possibilities for the Afro-Costa Rican subaltern to rise up and combat corruption and change social norms through its power of community and collective action. This action, according to Duncan, can be led by anyone and it is for this reason that although the injustices of racism and class prejudices are used to forge a sympathetic bond between Kimbo's plight and the reader, Kimbo is not depicted as a flawless character. Instead, he is seen to be a complex and realistic figure for whom Duncan builds sympathy without eulogizing him. This is made clear as his second wife describes him as 'era un hombre... Así con defectos y todo. Así somos todos' [he was a man... with defects and everything. We're all like that] (149), thus depicting the image of Kimbo as a 'man of the people' style hero. In this way Duncan asserts that those leading the subalterns' fight against hegemony do not have to be perfect individuals, but they must be willing to sacrifice in order to win this battle just as Kimbo chose to return from exile - despite the dangers - in order to challenge the authorities and bring about justice. It is therefore the injustice done to Kimbo in the pages of the novel which elicits a response from the reader, and Duncan's aim is that his audience should begin to recognize and resist established social divisions which harm the subaltern, rising up against civil society to combat unjust ideologies.

Mirroring these depictions of Kimbo's subalternity, the novel's society is also seen to be structured according to patriarchal order which serves as a mechanism used by the RSA and ISA to govern and manipulate Costa Rican society. In Kimbo, the roles played by central female characters, notably El Barrigón's wife, depict the deconstruction and interrogation of preconceived norms. None of the female characters in the novel are given a name, although as El Barrigón's wife begins to recover her identity, she is given a voice through the firstperson narrative. It is through her eyes that the pervasive and negative powers of patriarchy

\footnotetext{
11 The Semamfo is the power of one's ancestors that is felt as a spiritual power and is common in Afro-Costa Rican syncretic religious practice. For more see Harvey-Kattou, 2017: 187-198.
} 
are seen, and just as she narrates that her and her sisters were confined to their parents' house when her brother committed suicide, she also states that she had to marry El Barrigón as her only means of escape. When reflecting on her husband's kidnapping and comparing it to the aftermath of her brother's suicide, she states: 'en el fondo lo que hacía falta era un hombre. Ese era el vacío' [at the heart of the matter what was missing was a man. That was the void] (63). It is with this explanation that the reader comes to see that the patriarchs of the family her father in the first instance and her husband in the second - rule by both violence and oppression, driving women to anxiety, madness and depression (65-6). Although Althusser does not include the family unit in his definition of the RSA or ISA, it is clear that Duncan believes the private family home to be just another vehicle for the perpetuation of social norms as, just as these women are not allowed to leave the home alone or speak publicly, they are also not allowed voices even in private for fear of violent physical and emotional reprisal, thus showing them as subaltern subjects.

According to Paulette Ramsey, El Barrigón's wife's position in the novel denotes 'the threat of submersion or domination, the problem of self-definition and struggles with feelings of alienation' which are felt by all marginalized social groups (2002: 319). In her desperation to escape her family, she was forced to give up any rights as an independent person when marrying El Barrigón, as:

él no la dejó trabajar. El hacía las compras. Tampoco la dejaba hacer trabajo en la casa. Su función, su única función era ser bella, lucir elegante. No tenía nada más que hacer. No debía salir sola: él la acompañaba siempre.

[he did not let her work. He did the shopping. He didn't let her do housework either. Her function, her only function, was to be beautiful, to look elegant. She did not have anything else to do. She shouldn't go out alone: he was always with her] (67)

In line with Gayatri Spivak's Marxist feminist critique, she notes that within the framework of use, exchange and surplus value "the woman in the traditional social situation produces more than she is getting in terms of her subsistence, and therefore is a continual source of the production of surpluses, for the man who owns her, or by the man for the capitalist who owns his labor-power' (in Landry and Maclean 1996:56). El Barrigón's home, however, does not seem to fully comply with this stereotype, as although his wife is forced to stay at home, or to be his trophy when at events, she is not given a function further than the aesthetic or the decorative. Even the role of buying food, cooking and cleaning - one usually associated with 
women - is denied her, and in this way Duncan demonstrates the intersectionality of gender and class discrimination, and the roles expected of women from different social strata. As $E l$ Barrigón is a man of substantial means, he has been able to purchase a young, beautiful wife, and he has given her a specific purpose and place in his life - to look good and say the right things.

Unlike Kimbo, who has no agency due to dual discrimination, however, El Barrigón's wife does gain awareness of her situation which eventually leads her to rebel against both husband and patriarchal social order in the novel - something she is able to do as a monied member of the middle classes. When the ransom note for the safe return of her husband arrives, she realizes that she has no idea how to access his money, quickly adding 'Y yo no tengo palabra. Yo no sé hablar' [I don't have a say. I don't know how to speak] (69). This voicelessness comes from being 'la propiedad personal del Barrigón' [El Barrigón's property] (93) rather than being her own self, and it is clear that her compliance with this situation comes from the belief that this is the natural, spiritual order of things. Indeed, she looks at the Bible and comments: 'la mujer, decía, nacía para ser compañera del hombre, para llenar de alegres momentos su vida, para compartir sus depresiones' [woman, it is said, was born to accompany man, to fill his life with happy moments, to share his depressions] (93), again demonstrating the extent to which the Church plays its role as an ISA in society. It is during these ruminations, however, that she starts to question established social norms encouraging the reader to do the same - and in this way Duncan indicates the positive effects of challenging and inverting normative social roles. Indeed, the longer El Barrigón's wife occupies the house without her husband in it, the more she begins to break free from the psychological chains with which civil society has bound her, stating firmly that she will be 'sí, ser mujer, pero ser persona. Ser mujer pero no decorativamente [...] Libre. Mujer, pero yo. Mujer yo. Persona yo. Mujer-persona, yo' [yes, be a woman, but be a person. Be a woman but not decoratively [...] Free. Woman, but me. Woman me. Person me. Woman-person me] (97). This affirmation of her identity and independence, and her struggle to be recognized as an individual with a voice, are the opportunities denied to Kimbo as he is gunned down as soon as he tries to speak, and yet these form the hopeful basis of the novel's ending, whereby Kimbo's wife and El Barrigón's wife narrate the collective culpability of society for Kimbo's death and choose to use Kimbo's posthumous letter to challenge civil society and prevailing ideology. Although this is their first meeting, their powerful recognition of gender, race and class injustice and their desire to fight against it implies a spirit of rebellion has been forged 
by these two women, one which they will take forward into the future. It is in this way that Duncan aligns the violence and marginalization faced by women, Afro-Costa Ricans and the poor as subaltern struggles against the State's hegemony, encouraging the reader to stand with the wives against the repressive mechanisms of civil society.

\section{The Culprit: The Cult of Individualism}

Despite the various crimes committed in Kimbo at the hands of the RSA and ISA against these subaltern victims, then, it is clear that ultimate culpability lies with the culture of individualism which is a core part of Costa Rica's capitalist society. According to Althusser, it can be argued that although ideology remains an intangible concept or set of beliefs, it must necessarily have a material existence in that each individual must act according to his own ideology (1971: 165). Althusser describes this coming-to-consciousness of one's own ideology and actions - which may have until this point been performed unthinkingly - as the interpellation of ideology which turns the individual into a subject (1971: 175). The interpellation of the RSA and ISA agents within Kimbo is seen as each of these slowly comes to recognize the ideology to which they have adhered and upon which they have acted, as they recuse themselves of blame while also realizing they have formed part of the reproduction of established social order, unrepentantly acting against the subaltern. Duncan therefore uses this novel to make the point that it is the actions of individuals in the name of self-preservation which render society as collectively culpable for injustice.

The policeman is the first to demonstrate this coming-to-consciousness as he states that "yo estoy empezando a creer que de veras este muchacho no tiene nada que ver en el asunto' [I'm starting to think that this guy really didn't have anything to do with it] (28-9), and yet he goes on to continue to interrogate and torture Kimbo, explicitly stating that he prefers to do his job by obtaining a (false) confession than to do what is just. Other RSA and ISA representatives also attempt to absolve themselves of guilt when ideology interpellates them, making them aware of the part they have played in injustice. The Priest, for example, did not see Kimbo at the site of the kidnapping, but even when he realizes this he prefers to stay silent rather than lose face in public. The court clerk is also aware that he acted selfishly, stating 'lo sé y yo lo sé en forma privada y no tengo derecho alguno a pasar la información a nadie. Por lo menos eso me dije' [I know something and I know it confidentially and I don't have the right to pass on that information to anyone. At least that's what I told myself] (107), attempting to 
convince himself that he was right to continue to merely do his job regardless of the consequences. It is also made clear he acts selfishly, lying in order to keep his job but telling himself he is acting for the social good: 'uno trabaja para el Estado, y no tiene caso destruir la confianza del ciudadano en los hombres del Estado' [you work for the State, and there's no reason to destroy the citizen's trust in the State's workers] (130). The motives for the lies of the culpable parties and the very idea of working towards a greater, common good are therefore actually seen to be no more than acts of selfish individualism. Other characters are also seen to have internalized the ideology of individualism, as both the alcoholic and Kimbo's ex-wife play a conscious part in the injustice against Kimbo. The alcoholic who was paid to bear false witness goes to confession to absolve himself - in the heart of the ISA, the Catholic Church - and states he did it because 'amo a los míos y tenía que salvarlos' [I love my own and I had to save them] (109) - therefore insinuating that putting one's own family before justice and truth is correct behaviour. Kimbo's ex-wife, who is the first person to accuse Kimbo, also makes it clear that she did so for selfish means. At the beginning of their relationship 'se fue adueñándose de él poco a poco... lo redujo a su círculo, a un perímetro exclusivo dentro del cual sólo tenían cabida él y ella, ella y él' [she started to take possession of him bit by bit... she reduced him to her circle, an exclusive perimeter in which there was room for him and her, her and him] (87), and, having lost him to another woman, she states 'me dolerá verlo pudrirse en la cárcel, pero tendría que ser así. He jurado que será mío o de nadie' [it will hurt me to see him rot in jail, but it has to be this way. I've sworn that he'll be mine or no one's] (90), therefore explaining that her wishes must come before the fulfilment of justice.

The link between this spirit of individualism and hegemonic capitalist values is also noted by Duncan. Althusser contends that the interpellation of an ideology ends in "the absolute guarantee that everything really is so, and that on condition that the subjects recognize what they are and behave accordingly, everything will be all right' (1971: 181), and it is for this reason that each individual acts according to the social rules of capitalism in the novel. In order to succeed, Kimbo had to join the drive towards consumerism, as his friend describes his rags-to-riches life as: 'Habían surgido, si surgir es estar mejor que la mayoría de los habitantes del país. Estaban en el sector que tenía crédito; entre los que habían logrado comprar casa y automóvil porque tenían crédito' [They had made it, if making it is being better off than most inhabitants of the country. They were in the credit sector; among those that had been able to buy a house and car because they had credit] (40). This depiction of 
having arrived in a new social sector because of what one owns - even if ironically this is on credit only - shows that class, wealth and being in the possession of material goods are part of the established social hierarchy. Indeed, even for a member of the middle classes like $E l$ Barrigón, money is the key to maintaining social status and, therefore, power. He states that 'todo el mundo sabe que soy un hombre solvente. Todos ven la forma en que yo vivo; soy un ciudadano respetable' [everyone knows I'm solvent. Everyone sees how I live; I'm a respectable citizen] (58), clearly demonstrating that he ties money and the possession of material goods to respect and therefore class hierarchies. Duncan therefore demonstrates that social mobility itself is a door closed to many people in the country and that the enforced segregation of members of society by social class is the product of the creation of capitalist social order which forces people to act according to selfish interest rather than as a community which values all its members equally. It is therefore this ideology through which the nation is portrayed as a crime scene due to the corrosive power of the State.

While the blame for the injustices of the novel do not entirely lie with the perpetrators of the crimes themselves, then - and indeed little attention is paid to the CNDC who committed the kidnapping in the first place - it is society's individualism and adherence to capitalist values which leads to the conclusion of the collective culpability of society itself. Duncan hints at this throughout the novel, gradually building up a case against society which culminates in Kimbo's wife making this point explicitly when she states 'la culpa no está en ninguno en particular sino en todos' [no one person is at fault, all of us are] (43) ${ }^{12}$ and, when she is asked who killed Kimbo, 'mucha gente tuvo que ver. Los que hablaron y los que callaron también' [lots of people had something to do with it. Those that spoke and those that did not too] (149). Prior to these assertions, Duncan maintained the faceless and nameless characteristics of all the protagonists to ensure the reader did not apportion blame to one particular individual. The witnesses at the trial, for example, are described as: 'desfilaron uno por uno todos los testigos y todos los testigos eran el testigo' [the witnesses filed past one by one and all the witnesses were the witness] (14). The fact that all the witnesses merge into one denotes society's culpability as a whole, and this is again highlighted when the priest takes

\footnotetext{
12 This statement is reminiscent of other multi-accomplice crime fictions, notably Agatha Christie's Murder on the Orient Express (1934) in which a child murderer is acquitted due to police and judicial failings, leading several people connected to the case to take their own revenge by each stabbing the victim in turn. While Kimbo is shot by one gunman, it is made clear in Kimbo that it is State failings that have led to the real criminals getting away, and society's fault that the wrong man was imprisoned and then killed for the original crime, as if they had all pulled the trigger. The key difference in these two narratives, of course, is Ratchett's guilt and Kimbo's innocence, demonstrating the dangers of trial by public opinion due to internalized prejudices.
} 
confession from the alcoholic, stating 'la verdad surgía de lo que habían visto todos' [the truth came out of what everyone had seen] (73). The irony in this statement is, of course, that no one had actually seen Kimbo kidnap El Barrigón at all, but their blind faith in the established social order - racism and class prejudice - created a belief that they had. That daily routine, habitual acts and the repetition of words and phrases are frequently employed by Duncan throughout this text also emphasizes the fact that the unwillingness to question or break with habit is what creates and perpetuates norms which may seem innocuous at first stamping and signing papers all day, for example - but which when adhered to too rigidly can become dangerous - not denouncing the real kidnappers. Duncan's novel is therefore summarized by El Barrigón's wife when she states 'sigo pensando que en el fondo hemos perdido todos. Y en alguna medida todos fuimos responsables' [I keep thinking that, really, we have all lost. And in some way we were all responsible] (141). The message for the reader, then, is to accept responsibility not only for one's actions, but also for one's inaction, always questioning the impulse to act on individualist motives rather than following a social consciousness.

\section{Conclusion}

Karl Marx, upon whose theories Gramsci and Althusser's visions of society are built, stressed that 'men make their own history but they do not make it as they please; they do not make it under circumstances chosen by themselves but under circumstances encountered, given and transmitted from the past' (1972: 245). While the circumstances in which Kimbo is set are not chosen by any of the characters in the novel, they certainly make their own, continuing, sense of history as they perpetuate the established order they have inherited. Duncan uses this work as a form of soft power to make the social divisions - hegemony, civil society and the subaltern - clear to the reader, forcing sympathy with marginalized groups and encouraging a mobilization against social norms. The lesson for his audience lies in the notion of collective versus individual responsibility, whereby due to a dominant politics of individualism, no one acts for the good of the group as a whole despite constantly proclaiming that this is exactly what they are doing. Indeed, we see that the decisions of individuals, which may appear small or easily justifiable to them, work together to form negative consequences which reverberate around the entire country. The RSA and ISA - encapsulated here by the police, judiciary and Church - are seen to be the repressive deputies of the state, and as El Barrigón's wife sums 
up, it is the entire nation - society itself - which is responsible for the crimes committed in the novel. This collective culpability pointed at by the book's denouement signals the message that society's ills are the fault of all - the hegemonic power included - and that no individual should escape their role. This idea, however, is seen to be at odds with the Costa Rica depicted by Duncan, which prides individualism, materialism and capitalist gain over moral concerns. Indeed, the entire novel goes some way to setting out an argument for social mobility and against discrimination, both of which are necessary components of a stratified, hierarchical, capitalist society. Although Duncan does not suggest a political alternative to the ideology he appears to oppose, he instead demonstrates the positive outcome of questioning the dominant norms of established social order just as Althusser and Gramsci propose. In this way, the scene of the crime in Kimbo - Costa Rican society - is as important as the crimes committed in the novel themselves, leading the reader to pinpoint the culprit of individualism which is used by civil society to commit crimes and reap injustice upon the marginalized subaltern in order to maintain established social order. 


\section{Works Cited}

Althusser, Louis, Lenin and Philosophy and Other Essays, Ben Brewster, trans., (New York: Monthly Review Press, 1971).

Beverley, John, Subalternity and Representation: Arguments in Cultural Theory (London: Duke University Press, 1999).

Biesanz, Mavis Hiltunen, Karen Zubris Biesanz and Richard Biesanz, The Ticos: Culture and Social Change in Costa Rica (London: Lynne Rienner Publishers, 1999).

Bourdieu, Philippe, Outline of a Theory of Practice (Cambridge: Cambridge University Press, 1977).

Christian, Michelle, ' ... Latin America without the downside': racial exceptionalism and global tourism in Costa Rica', Ethnic and Racial Studies 36/10 (2013), 1599-1618.

Duncan, Quince, Kimbo (Costa Rica: Editorial Costa Rica, 1989).

González Zúñiga, Julián, ‘Quince Duncan y sus aportes a la literatura costarricense’, Repertorio Americano 24 (2014), 395-401.

Harvey-Kattou, Liz, 'The Supernatural as Decolonial Tactic: Afro-Costa Rican Motifs in Quince Duncan's Fiction', in Stephen Hart and Zoltan Biedermann, eds., From the Supernatural to the Uncanny (Cambridge: Cambridge Scholars Publishing, 2017), 187-98.

Hoare, Quintin and Geoffrey Nowell Smith, Selections from the Prison Notebooks of Antonio Gramsci (London: Lawrence \& Wishart, 1971).

Landry, Donna and Gerald Maclean, The Spivak Reader (London: Routledge, 1996).

Padover, Saul, ed., The Karl Marx Library Volume One (McGraw Hill: New York, 1972).

Pezze, Andrea, 'El género policial en Centroamérica: entre peculiaridad local y episteme latinoamericano', Boletín AFEHC 69 (2016), 1-18.

Quesada Soto, Álvaro, Breve historia de la literatura costarricense (San José, Costa Rica: Editorial Costa Rica, 2008).

Quirós, Daniel, 'Más allá de la paz: Literatura de crímenes en la Costa Rica contemporánea', in Gustavo Forero Quintero, ed., Memoria de crímenes: Literatura, medios audiovisuales y testimonios (Bogotá: Siglo de hombres editores, 2017), 119-142.

Ramsey, Paulette, 'From Object to Subject: The Affirmation of Female Subjectivity in Quince Duncan's La paz del pueblo and Kimbo', in Patricia Mohammed, ed., Gendered Realities: 
Essays in Caribbean Feminist Thought (Jamaica: University of the West Indies Press, 2002), 314-23. 